\title{
AEROMAGNETIC AND INFERRED PRECAMBRIAN PALEOGEOLOGIC MAP OF EAST-CENTRAL MINNESOTA AND PART OF WISCONSIN
}

By

P. K. Sims and Isidore Zietz

GEOPHYSICAL INVESTIGATIONS

MAP GP-563

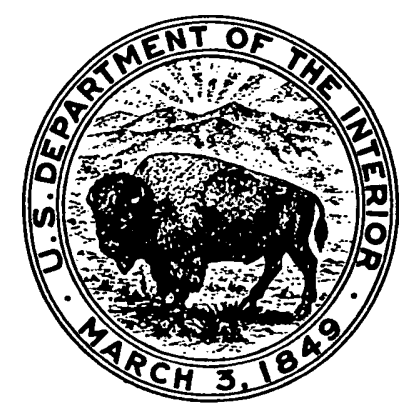

PUBLISHED BY THE U. S. GEOLOGICAL SURVEY 